\title{
FDI, service intensity, and international marketing agility
}

Article

Accepted Version

Li, R., Liu, Y. and Bustinza, O. F. (2019) FDI, service intensity, and international marketing agility. International Marketing Review, 36 (2). pp. 213-238. ISSN 0265-1335 doi: https://doi.org/10.1108/imr-01-2018-0031 Available at https://centaur.reading.ac.uk/78749/

It is advisable to refer to the publisher's version if you intend to cite from the work. See Guidance on citing.

To link to this article DOI: http://dx.doi.org/10.1108/imr-01-2018-0031

Publisher: Emerald

All outputs in CentAUR are protected by Intellectual Property Rights law, including copyright law. Copyright and IPR is retained by the creators or other copyright holders. Terms and conditions for use of this material are defined in the End User Agreement.

\section{www.reading.ac.uk/centaur}

\section{CentAUR}

Central Archive at the University of Reading

Reading's research outputs online 


\title{
FDI, service intensity, and international marketing agility: The case of export quality of Chinese enterprises
}

\begin{abstract}
Purpose - This paper aims to provide a nuanced understanding of international marketing agility by connecting organizational capability literature with that of standardization and adaptation. The focus of the research is to clarify whether managing the tension between product standardization and service customization generates an extra premium in international markets.

Design/methodology/approach - Two disaggregated Chinese datasets, the Annual Survey of Industrial Enterprises (ASIE) and the China Customs Database, are used for developing an econometric model. Export quality improvement is the outcome variable in reflecting the effect of international marketing agility on performance.

Findings - International marketing agility is reached through upstream FDI intensity, particularly in the context of service FDI. Manufacturing sectors with higher service intensity have more agility, being more likely to generate export quality.

Research limitations/implications - This study makes three theoretical contributions by (1) clarifying the concept of international marketing agility as an organizational capability generated by manufacturing standardization and service customization; (2) investigating the influence of upstream FDI intensity for export quality while taking into account the industry contexts; and (3) obtaining an enhanced understanding of the service intensity of manufacturing firms on export quality.

Originality/value - We offer a nuanced and contextualized understanding of international marketing agility and explore the complex relationships between FDI, service intensity, and export quality.

Keywords - International marketing agility, FDI, Service intensity, China, product quality Paper type - Research paper
\end{abstract}




\section{Introduction}

International marketing agility deals with the need of customizing enterprises' marketing strategies to satisfy international customers (Jain, 1989). As an emerging concept, international marketing agility can be traced back to the notion of strategic agility. As an organizational capability, agility denotes the ability to manage the trade-offs between the commitment of resources to current goals with shifting market needs (Carmeli et al., 2017; Fourné et al., 2014; Gibson and Birkinshaw, 2004; Weber and Tarba, 2014). For instance, strategic agility can help firms remain competitive in international environments in the pursuit of strategic renewal (Lewis et al., 2014; Junni et al., 2015). However, while the existing literature on agility tends to be dominated by the strategic aspect, it lacks sufficient theoretical underpinnings. We argue that international marketing literature may offer some interesting insights to theoretically advance the concept of international marketing agility, especially stemming from the debate between the standardization marketing strategy needed for domestic markets and the adaptation required in the different countries where enterprises operate (Tan and Sousa, 2013).

International marketing agility is an organizational capability that allows firms to better formulate domestic market approaches (i.e., standardization) while customising their existing strategies to approach international markets (i.e., adaptation). In this paper, international marketing agility can be defined as the ability of organization in swiftly applying marketing practices contingent upon domestic and international market situations. In those international markets, performance depends on the degree of customer satisfaction linked to the perception of product heterogeneity (Anderson et al., 1997; Crozet and Milet, 2017). Therefore, international marketing agility may be linked to higher export performance as it increases heterogeneous customers' positive perception and satisfaction. Thus, variables related to increased export quality and performance as Foreign Direct Investments (Barrel and Pain, 1997) should be considered in framing international marketing agility. This study argues that export quality of downstream domestic enterprises may be affected by upstream FDI.

A definitive understanding of the relationship between Foreign Direct Investments (FDI) and export quality tends to be elusive in the existing literature. Some scholars suggest that high-quality upstream FDI can provide much more efficient and a greater variety of 
intermediaries to downstream manufacturing enterprises (Sun et al., 2015), whereas others argue the influence is marginal or negligible as technology spillovers from FDI may squeeze out domestic enterprises due to the impact of competition (Aitken and Harrison, 1999; Herzer, 2012). Nevertheless, firm heterogeneity plays an important role in the relationship between upstream FDI and firm performance (Damijan et al., 2013). Therefore, the purpose of this paper is to obtain an enhanced understanding of the relationship between international marketing agility and firm performance related to manufacturing or service contexts, and clarify whether managing the tension between product standardization and service customization generates an extra premium in international markets. To achieve this objective, this research analyses how upstream FDI — the extent of local firms' forward linkages in downstream sectors with MNEs (Girma and Gong, 2008)—generates international marketing agility and increases export quality. Thus, this paper addresses a first research question: considering sector context, how would the upstream FDI affect the downstream enterprises with regard to export quality?

Firms operating in international markets need to consider how the type of products (e.g., manufactured good or services) affects their international marketing strategy (Baalbaki and Malhotra, 1993). Moreover, there is an increasing tendency in manufacturing firms towards servitization in their offerings (Rabetino et al., 2018; Vandermerwe and Rada, 1988), creating hybrid portfolios of products and services (Vendrell-Herrero et al., 2018a, 2018b). Therefore, strategic approaches to international marketing for manufacturing firms are deployed by considering the appropriate combination of product-service offering and level of customization required (Ulaga and Reinartz, 2011). Furthermore, even within the manufacturing industry, different levels of service, or service intensity, across manufacturing sectors may affect export performance outcomes differently. Recent research on servitization reveals that different manufacturing industry sectors are associated with different levels of service intensity (Bustinza et al., 2017a; Crozet and Milet, 2017). Such a nuanced approach with regard to servitization awaits further empirical validation and theoretical refinement. Previous research has suggested that service intensity is closer to customization than to standardization (Lovelock, 2001). Arguably, from the perspective of marketing, standardization is a manufacturing goal while customization is the normative goal (Vargo and Lusch, 2004). Thus, 
we argue that agility in international marketing can be developed through service intensity. Thus, the second research question addressed is this: what would be the influence of service intensity of manufacturing firms on export quality? Both research questions address the role of international marketing agility in enhancing export quality, first by considering whether manufacturing or service firms are affected differently by upstream FDI, and then by analysing whether upstream FDI affects high and low service intensity manufacturing sectors differently.

The research setting of this paper is China's manufacturing export competitiveness. Many theoretical and empirical studies have indicated that China is still located in the low-end of the global value chain. To realize the transformation and upgrading of the value chain by making better use of domestic and foreign resources is critical for strengthening China' s real economy. China has consistently received the greatest amount of FDI of any developing country since 1992. In 2014, China even exceeded the United States in attracting FDI (UNCTAD, 2015). In the beginning of 2017, the Chinese State Council affirmed that China will further relax FDI access to services, manufacturing, mining, and other areas. Improvement in export quality is a way to reflect the firms' transformation and value chain upgrading while FDI, especially service FDI, as important input into manufacturing firms, will greatly affect upstream enterprises. Because with the new trend of the servitization, service input will play a much more important role in decreasing cost or facilitating differentiation (Ulaga and Reinartz, 2011), improving product quality and realizing the value chain upgrading compared with manufacturing input. Accordingly, we will use an econometric model to estimate the effect of upstream FDI on the export quality of firms by following previous studies (Bas and Strauss-Kahn, 2015; Feng et al., 2016; Xu et al., 2017).

This study provides three important theoretical contributions to international marketing agility research. First, our study contributes to a nuanced and contextualized understanding of international marketing agility by combining literature on organizational capability and international marketing. Second, our findings highlight the industry contexts, namely the service and manufacturing industries, and reveal FDI intensity can affect export quality differently due to different levels of international marketing agility. Third, our study contributes to servitization research from an international perspective by joining the recent 
conversation on service intensity across manufacturing sectors (Bustinza et al., 2017b; Souchon et al., 2016).

This paper is organized as follows. We first review the conceptual background on international marketing agility and its relation to FDI, service intensity, and export quality, and subsequently develop hypotheses. We then present our research methodology and results. We conclude this paper by discussing the implications for theory and managerial practice and suggest future research directions.

\section{Conceptual background}

\subsection{International marketing agility}

Agility, from an organizational capability perspective, is the ability to manage trade-offs between the commitment of resources to current goals with shifting market needs (Gibson and Birkinshaw, 2004). Some authors make distinctions between the dimensions of customer agility, partnering agility, and operational agility, each with the objective of aligning enterprises' objectives with the flexibility and speed that markets require (Bustinza et al., 2018; Cunha et al., 2018; Sambamurthy et al., 2003; Verma et al., 2017). Agility is achieved by instilling capabilities for responding to changing markets, particularly important in international contexts where diversity in the environment is greater (Grewal and Tansuhaj, 2001). Therefore, among the set of organizational capabilities, international marketing agility is the capability that allows for flexibility and time responsiveness in developing international strategies (Shenkar, 2010). This particular agility helps enterprises to effectively change their course of action while maintaining competitiveness in international environments (Junni et al., 2015).

International marketing agility deals with the need to customizing enterprises' marketing strategies to satisfy international customers (Jain, 1989). This introduces the conflict between the standardization marketing strategy needed for domestic markets and the adaptation required in the different countries in which enterprises operate (Tan and Sousa, 2013). Thus, enterprises aim to develop specific capabilities that allow them to reconfigure their resources for deploying effective marketing strategies when operating in international markets (Craig and Douglas, 
2005). These specific capabilities are related to the organizational ambidexterity needed for simultaneously balancing exploitation and exploration (Gupta et al., 2006) while achieving alignment with and adaptability to the particular markets entered (Tan and Sousa, 2013). Some authors have argued that service infusion in product standardization has demonstrated unique and specific capabilities that allow the customization of offerings (Baines and Lightfoot, 2013; Rabetino et al., 2018; Ulaga and Reinartz, 2011; Vendrell-Herrero et al., 2018b), helping enterprises to identify new ways to manage the business transformation needed in international settings. In sum, service innovation is considered leverage for developing distinctive capabilities (Baines et al., 2017), as the ones needed for achieving international marketing agility.

Understanding that strategic agility refers to a meta-level conceptual system suitable for application within different disciplinary domains, we consider international marketing agility to be an aspect of strategic agility (Brannen and Doz, 2012; Brown and Eisenhardt, 1997; Brueller et al., 2014; Doz and Kosonen, 2008b; Dyer, and Ericksen, 2005; Lukka and Vinnari, 2014; Weill et al., 2012). Therefore, the aim of employing international marketing agility in the context of service intensity is gaining new insights in this novel concept.

\subsection{International marketing agility and upstream FDI}

\subsubsection{The impact of upstream FDI on international marketing agility}

Since the reform and opening up period, China's economy has developed rapidly. International trade and FDI have contributed greatly to economy development. In order to give full play to the important role of FDI, most developing countries have strict requirements in attracting different types of FDI in order to realize the transformation and upgrading of the economy. For example, they request that FDI be high-technology intensive and environmentally friendly, and foreign companies are urged to establish close relationships with the domestic enterprises in order to foster innovation outcomes (Collinson and Liu, 2017). Therefore, high-quality upstream FDI, as an important input, can provide much more efficient as well as a greater variety of intermediaries to downstream manufacturing enterprises (Sun et $a l, 2015)$. It is helpful for the manufacturing enterprises to produce more customized products 
for the customers. Therefore, it may increase the international marketing agility of the exporting enterprises.

Another important aspect is the technology spillover effect of FDI. While some literature has argued that technology spillover effect of FDI can be negligible, even it may squeeze out of the domestic enterprises because of the competition effect (Aitken and Harrison, 1999; Herzer, 2012). Other literature has suggested that the spillover effect of FDI depends on the industries of the FDI, the heterogeneity of the domestic enterprises, the origin of FDI, and the entry tenure of the FDI (Altomonte and Petinings, 2009; Javorcik and Spatareanu, 2011; Meyer and Sinani, 2009; Zhang, Li and Li, 2014). For instance, previous research has shown that high-quality FDI has a strong technology spillover effect not only in horizontal (Baltabaev, 2014) but also in vertical industries (Du et al., 2012; Girma et al., 2015; Liu et al., 2009). In order to utilize the inputs more efficiently, the upstream enterprises will try to provide more technological assistance and management training for the downstream enterprises, which will, in turn, increase their productivity. Highly productive enterprises will have developed capabilities to respond to changing markets, which means they will have more international marketing agility.

In addition to China's economic development by attracting inbound FDI, recent phenomena have demonstrated the globalization of emerging market firms' catch up strategy, such as the cross-border acquisitions found in advanced economies (Cui et al., 2014; Liu and Vrontis, 2017) and outbound FDI (Xing et al., 2016). Chinese overseas acquisitions are associated with peculiar characteristics referred to as 'light-touch integration' in managing the post-acquisition process (Liu and Woywode, 2013). Even against this 'light-touch integration' approach, Chinese companies are still able to leverage the strategic assets acquired abroad, such as brand (Liu et al., 2018). In so doing, they foster the emerging market firms' catch-up strategy and their flexibility in international competition.

\subsubsection{The role played by upstream FDI intensity in enhancing export quality considering industry characteristics}

Because of the distinctive characteristics of the manufacturing and service industries (Green et al., 2017), the upstream FDI may play a different role in two mechanisms. First, compared 
with the manufacturing industry, the service industry contains much more knowledge, technology, information, and human capital, making their offers more varied (Arnold et al., 2011; Vendrell-Herrero et al., 2018a; Zhang et al., 2013). For example, upstream FDI on downstream commercial services' firms is a critical source of new knowledge, technology, and advanced management methods (Vandermerwe and Rada, 1988). Furthermore, other downstream enterprises, as financial services' firms, can not only decrease financial constraints but also initiate $R \& D$ activities thanks to the financial support provided by upstream FDI (Raff and Ruhr, 2007). Second, productive services tend to be associated with a much stronger technology spillover effect because of their high technology intensity (Amiti and Wei, 2009). This can decrease the production cost by increasing the productivity of the enterprise (Abernathy and Utterback, 1978). Therefore, upstream FDI specifically increases knowledge transfer (Smeets, 2008), R\&D activity (Griffith et al., 2004), and resources productivity (Fernandes and Paunov, 1978) in the service sector. Bearing in mind that knowledge, R\&D activities, and resources are critical in developing strategic agility (Doz and Kosonen, 2008a, 2008b, 2010), we argue that upstream FDI intensity in the service industry can greatly increase international marketing agility and the adaptation required in different countries. The more internationally agile the enterprise is, the better the offerings may suit international customers' heterogeneous demands, thereby increasing export quality. Furthermore, the upstream FDI can play an important role in enhancing international marketing agility specifically for downstream enterprises. Downstream firms obtain greater benefits from the managerial, organizational, and technical skills that the MNEs provide them (Girma and Gong, 2008); thus export quality should be improved. According to the foregoing, we propose the following:

H1a: Upstream FDI intensity in the service industry improves the export quality of the downstream enterprises.

H1b: The impact of upstream FDI intensity in the manufacturing industry on the export quality of the downstream enterprises is weaker than in the service industry.

\subsection{International marketing agility and service intensity}




\subsubsection{Developing international marketing agility through service intensity}

Since Utterback and Abernathy's (1975) framework, Product innovation has been conceptualized as a predictable model that follows three stages: product performance, product variety, and product standardization. As a result of this process, manufacturing enterprises build a product's installed base (IB), defined as the total number of products currently offered (Oliva and Kallenberg, 2003), and that constitutes their market portfolio. Nevertheless, manufacturing enterprises are increasingly including service to their product's IB in search of a competitive advantage (Baines et al., 2017; Rabetino et al., 2018). Thus, enterprises are deploying a service's IB-range of related services over the useful life of a product and transitioning from their initial product-oriented services to more developed result-oriented services (Tukker, 2004). While servitizing the product's IB, distinctive capabilities arise (Ulaga and Reinartz, 2011; Vendrell-Herrero et al., 2018a), in an overall process defined as servitization (Vandermerwe and Rada, 1988) or Product-service innovation (Bustinza et al., 2017a; Vendrell-Herrero et al., 2018a).

Service intensity is closer to customization than to standardization - that is, closer to non-standardization (Lovelock, 2001). From a marketing perspective, standardization is a manufacturing goal while customization is a normative goal (Vargo and Lusch, 2004). Therefore, manufacturing efficiency is determined by marketing effectiveness in an ambidextrous dialogue. This is particularly important in an international context, where cross-cultural differences are critical (Schmid and Kotulla, 2010). Thus, it can be inferred that international marketing agility comes at the expense of the strategic fit between manufacturing standardization strategy and service customization, as being service intensive is critical to achieving higher performance in international contexts.

\subsubsection{Service intensity and export quality}

Manufacturing enterprises develop product innovation as a means of standardizing products and minimising costs, the final objective being to achieve economies of scale (Utterback and Abernathy, 1975). Meanwhile, service intensity on manufacturing sectors has the aim of developing capabilities that are delivered through product performance (Baines et al., 2017). 
For Ulaga and Reinartz (2011), these distinctive capabilities are able to place the firm in a better cost position or differentiate them from competitors. Some authors have demonstrated that service intensity increases enterprises' resilience during economic crisis (Ariu, 2016a) as well as international exports (Ariu, 2016b; Lodefalk, 2014), helping enterprises to cope with market discontinuities. Furthermore, those manufacturing sectors with higher service intensity have higher firm performance (Crozet and Milet, 2017), leveraging performance on manufacturing enterprises that compete in higher R\&D industries (Bustinza et al., 2017a). Service intensity has contributed to increase firm performance in different environments in both Western (Bustinza et al., 2018) and non-Western contexts (Li et al., 2015). Therefore, it seems that service intensity develops particular and distinctive capabilities in the manufacturing enterprises that help them: it helps them to cope with market discontinuities, to better adapt in high R\&D competitive markets, and to compete in international markets. As a result, service intensity is related to the international marketing agility needed to be continually adaptive to market and technological discontinuities while maintaining a competitive advantage (Bustinza et al., 2017b). According to the foregoing, we propose the following:

H2: Manufacturing sectors with higher service intensity generate more export quality than other manufacturing sectors.

\section{Methodology}

\subsection{Overview of the research setting}

As a result of China' s reforms and progressive economic opening, its manufacturing export competitiveness has been greatly improved, but many theoretical and empirical studies have indicated that China is still located at the low end of the global value chain. It is important to realize transformation and value chain upgrading by making better use of domestic and foreign resources, which will strengthen the real economy of China. The Chinese economy over the past four decades can be described as mainly an FDI-driven model (Liu, 2017; Xing et al., 2018), and the inbound FDI and international trade have significantly contributed to Chinese economic development (Ricart et al., 2004). For instance, the Chinese government invited foreign companies to the country to form collaborative partnerships with Chinese 
organizations, such as joint ventures (Collinson and Liu, 2017). Amid the accumulation of capital and knowledge facilitated by FDI, Chinese companies began to compete with international competitors through globalization endeavours such as overseas mergers and acquisitions of strategic assets (Liu and Woywode, 2013) and outbound FDI in less developed countries, such as those in Africa (Xing et al., 2016).

The 19th CPC National Congress report repeatedly mentioned, 'China will not close its door to the world; we will only become more and more open' (中国开放的大门不会关闭, 只会越开越大), ‘making new ground in pursuing opening up on all fronts' , and 'develop an open economy of higher standards' (要对标更高的标准, 推动形成全面开 放新格局). FDI is one way of demonstrating a country's openness. Most of the studies indicate that FDI can enhance a country' s economic efficiency and assist in realizing the optimal allocation of resources. This can in turn help Chinese enterprises to move up along the global value chain through the use of high-quality international resources. According to statistics from UNCTAD, since 1992, China has been the recipient of the greatest amount of FDI of any developing country. In 2014, China even exceeded the United States in attracting FDI. In the beginning of 2017, the Chinese State Council promulgated two important documents: 'Some Measures on Expanding the Active Use of Foreign Capital in Opening up' 《关于扩大对外开放积极利用外资的若干措施》 and 'Notifications of Measures to Promote the Growth of Foreign Capital 《 《关于促进外资增长若干措施的通知》, which indicate that China will further relax FDI access to services, manufacturing, mining, and other areas.

Improvement in export quality is a way of reflecting firms' transformation and value chain upgrading. FDI, especially service FDI, as an important input to manufacturers, will greatly affect downstream enterprises. With the new trend of the servitization, service input will play a much more important role in decreasing the cost or facilitate differentiation (Ulaga and Reinartz, 2011), improving product quality and realizing the value chain upgrading compared with manufacturing input.

\subsection{Econometric model}


Based on the characteristics of the analysed context detailed in section 3.1, in this section we estimate the effect of upstream FDI on the export quality of sampled businesses. We follow Bas and Strauss-Kahn (2015), Feng et al. (2016), and Xu et al. (2017), among many other studies relating export quality of a firm to upstream FDI by including other control variables. We consider the following regression:

quality_firm $_{i j t}=\alpha+\beta u p_{-} F D I_{j t-1}+\gamma X+\varphi_{t}+\varphi_{j}+\varphi_{d}+\varepsilon_{i j t}$

where $i, j$, and $t$ denote firm, industry (2-digit Chinese Industrial Classification Level), and year, respectively. quality_firm is the export quality of a domestic firm. The key explanatory variable up_FDI refers to upstream FDI. We use its lag one-year value in order to control for potential simultaneity and reverse causality. More specifically, we use $u p_{-} f d i_{-} s, u p_{-} f d i_{-} m$ and $u p_{-} f d i$ to denote the upstream service FDI, upstream manufacturing FDI and comprehensive upstream FDI, respectively. X is the vector including the control variables. $\varphi_{t}, \varphi_{j}$, and $\varphi_{d}$ denote the fixed effect of year, industry, and region. $\varepsilon_{i j t}$ is the error term.

\subsection{Key variables}

1.Export quality of domestic firm (quality_firm). We adopt the method proposed by Hallak and Schott (2011), which is widely used by most literature. The essence of this approach is that given the price of a product, if the sales are much higher in a market, this means the product is of high quality. So first we should estimate the export function of the firm in a country.

Suppose for a certain product, the export quantity of firm $i$ in country $c$ is

$q_{i c t}=\rho_{i c t}^{-\sigma} \lambda_{i c t}^{\sigma-1} \frac{E_{c t}}{P_{c t}}$

where $q, \rho, \sigma, \lambda, E$, and $P$ denote quantity, price, elasticity of substitution of the product, consumer expenditure, and the price index, respectively.

Then, we take the natural logarithm of formula (2)

$\ln q_{i c t}=X_{c t}-\sigma \cdot \ln p_{i c t}+\varepsilon_{i c t}$ 
where $X_{c t}=\ln E_{c t}-\ln P_{c t}$ denotes the variable change with time and with the import country, and $\varepsilon_{i c t}=(\sigma-1) \ln \lambda_{i c t}$ is the error term, including product quality.

From equation (3) the product quality component emerges as follows:

quality $_{i c t}=\ln \hat{\lambda}_{i c t}=\frac{\hat{\varepsilon}_{i c t}}{(\sigma-1)}$

Then, we standardize the product quality

$$
r_{\text {quality }_{\text {ict }}}=\frac{\text { quality }_{\text {ict }}-\text { minquality }_{\text {ict }}}{\text { maxquality }_{\text {ict }}-\text { minquality }_{i c t}}
$$

where minquality and maxquality are the minimum and maximum of the product quality for firm $i$ within all the import countries.

The product quality ranges between 0 and 1 after standardization. The export quality of all the products produced by the firm i can be added together because they have no unit.

quality_firm $_{i t}=\frac{v_{i c t}}{\sum_{i m t \in \Omega} v_{i c t}} * r_{-} q u a l i t y_{i c t}$

where $\Omega$ denotes the sample set of all the export of firm $i$. quality_firm $i t$ is the average export quality of the firm. $v_{i c t}$ is the value that firm $i$ exports to country $c$.

2.Upstream FDI (up_FDI). First, we should calculate the share of foreign capital in an industry. $F D I_{\text {ratio }}=$ foreign $_{j t} /$ capital $_{j t}$, where foreign $_{j t}$ and capital $_{j t}$ are the foreign capital and total capital in industry $j$ in year $t$. Then, we use China' s Input-Output Table (I-O Table) in 2002 and 2007 to find the input index $\sigma$ of all the industries. Finally, we can calculate the upstream FDI of industry $j$ as follows:

$u p_{-} F D I_{j t}=\sum_{n, n \neq j} \sigma_{j n} * F D I_{-} r a t i o_{n t}$

where $\sigma_{j n}$ denotes the ratio of the input of industry $n$ in industry $j$.

If we want get the upstream service FDI, $\sigma_{j n}$ is the service input ratio. If we want get the upstream manufacturing FDI, $\sigma_{j n}$ is the manufacturing input ratio. If we want get the comprehensive upstream FDI, $\sigma_{j n}$ includes input ratio of all the industries.

\subsection{Control variables}

Control variables consist of the following 6 variables reflecting the enterprises' characteristics (Xu et al., 2017): (1) Total factor productivity, or TFP, ( $\left.t f p \_l p\right)$ is measured 
by the contribution to output other than labour and capital. In order to overcome simultaneity and selectivity biases by the OLS method, we adopt TFP estimated by LP method, which is proposed by Leninsohn and Petrin (2003) and has been widely used in the literature (Melitz, 2003; Yu, 2015). The essence of this approach is to use intermediate inputs as a proxy for unobservable productivity. (2) The profit rate of the enterprise (profit) is measured by the ratio of the total profit to total sales. If the enterprise has a high profit rate, it will have more funds to invest in $R \& D$, which helps the enterprise to improve export quality. (3) The financing constraint (finance) is measured by the ratio of short-term credits ${ }^{1}$ to capital assets (Liu et al., 2017). This is a special institutional constraint faced by Chinese enterprises (Manova, 2013). If this value is large, it means that the enterprise can easily obtain a bank loan, indicating that the enterprise pays less for external financing, which is good for the enterprise to increase the export quality. (4) The size of the enterprise (ln_size) is measured by the employment log. Larger enterprises have a scale economy, which is helpful for improving export quality by decreasing costs. (5) The age of the enterprise (ln_age) is measured by the log of the statistical year minus the establishing year of the enterprise plus 1 . Older enterprises will have more experience in decreasing costs, which is helpful for upgrading export quality. (6) Finally is ownership of the enterprise (State). If the enterprise is state-owned, then the dummy state equals 1 ; otherwise it equals 0 .

\subsection{Data}

This paper mainly relies on the following two disaggregated datasets: the first data source is the Annual Survey of Industrial Enterprises (ASIE) during the period 2003-2007, maintained by China's National Bureau of Statistics (NBS). The datasets cover all enterprises with sales greater than RMB 5 million. This dataset provides detailed information on each firm, including complete information on the three major accounting statements (i.e., balance sheets, loss and benefit sheet, and cash flow statements) and covers all the required variables used in the current study, such as employment, wage, sales, capital, fixed assets,

\footnotetext{
1 Where short-term credits=current liabilities-payable account-salaries payable-welfare payable.
} 
value added, and so on. We follow Brandt et al. (2012) to link enterprises over time using the originally assigned ID and other additional information such as name, industry, and addresses. Since NBS issued a new Chinese Industrial Classification (CIC) system in 2002, we employ the concordance developed by Brandt et al. (2012) to achieve consistency in the industry codes before and after 2002. Similar to the existing literature, we focus on enterprises in the manufacturing sector. However, some samples are still noisy and are therefore misleading; thus, we further follow Brandt et al. (2012) and Feenstra et al. (2014) to clean the datasets before estimation. Specifically, we drop a firm from the data if any of the following is observed: (1) the key financial variables (such as total assets, net value of fixed assets and sales, gross value of industrial output) are missing; (2) the enterprise has no identification number; (3) the number of employees hired for a firm is fewer than 8 people; (4) liquid assets are greater than total assets; (5) total fixed assets are greater than total assets; and (6) the net value of fixed assets is greater than total assets. The second set of data comes from the China Customs Database, which covers the information of imports and exports of all enterprises' 8-digit HS products. In order to calculate the export quality, we have to merge these two data using the enterprises' name, postal code, and telephone number separately, following $\mathrm{Yu}$ and Tian (2012) and Yu (2015). The average number of the merged enterprises is 53,912, which is more than $29 \%$ of the enterprises in the China Customs Database.

Moreover, in order to overcome the price fluctuation effect, we use the PPI of the various provinces to deflate the added value of the firm, and we use the fixed asset price index to deflate the capital of the firm. The PPI and fixed asset price index come from the Information Website of the Development Research Centre of the State Council (DRCnet). The data of FDI in manufacturing and service come from the China Statistical Yearbook and China Industry Economy Statistical Yearbook from 2003-2007. We use China's input-output table (I-O Table) in 2002 and 2007 to find the input index of all the industries.

Summary statistics for the selected variables are presented in Table I.

Table I. Summary statistics

\begin{tabular}{lllll}
\hline Variables & Definitions & Observations & Mean & SD \\
\hline
\end{tabular}




\begin{tabular}{lllll} 
quality_firm & Export quality of the firm & 113,736 & 0.571 & 0.176 \\
upfdi_s & Upsteam service FDI & 113,736 & 0.002 & 0.002 \\
upfdi_m & Upsteam manufacturing FDI & 113,736 & 0.192 & 0.190 \\
upfdi & Upsteam comprehensive FDI & 113,736 & 0.194 & 0.190 \\
$t f p \_l p$ & Total factor productivity & 111,769 & 7.175 & 1.193 \\
profit & Profit rate of the firm & 113,312 & 0.274 & 0.145 \\
finance & Financing constraint & 113,531 & 0.082 & 0.169 \\
ln_size & Size of the firm & 113,736 & 5.316 & 1.154 \\
ln_age & Age of the firm & 113,730 & 2.062 & 0.777 \\
state & Dummy of the state-owned firm & 113,736 & 0.106 & 0.308 \\
\hline
\end{tabular}

The correlation coefficient matrix is presented in Table II. We find that the absolute values of all of the correlation coefficients are far less than 1, and most of them are very significant, indicating that all of the explainable variables are uncorrelated. There is no multicollinearity problem.

Table II. Correlation coefficient matrix

\begin{tabular}{|c|c|c|c|c|c|c|c|c|}
\hline & upfdi_s & upfdi m & upfdi & $\mathrm{tfp} l p$ & profit & finance & ln size & ln age \\
\hline upfdi_s & 1 & & & & & & & \\
\hline upfdi m & $0.122 * * *$ & 1 & & & & & & \\
\hline upfdi & $0.134 * * *$ & $1.000 * * *$ & 1 & & & & & \\
\hline $\mathrm{tfp} l \mathrm{p}$ & $0.037 * * *$ & $0.016^{* * *}$ & $0.017 * * *$ & 1 & & & & \\
\hline profit & $-0.002 * *$ & $-0.003 * *$ & $-0.003 * *$ & $0.234 * * *$ & 1 & & & \\
\hline finance & $0.047 * * *$ & $0.059 * * *$ & $0.059 * * *$ & $-0.051 * * *$ & $-0.122 * * *$ & 1 & & \\
\hline ln size & $-0.019 * * *$ & $-0.032 * * *$ & $-0.032 * * *$ & $0.536 * * *$ & $0.041 * * *$ & $0.007 * *$ & 1 & \\
\hline ln age & 0.00500 & $0.015 * * *$ & $0.015 * * *$ & $0.203 * * *$ & $-0.006 * *$ & $0.053 * * *$ & $0.326 * * *$ & 1 \\
\hline
\end{tabular}

Note: $* * * * *$, and $*$ denote significant at the $1 \%, 5 \%$, and $10 \%$ levels, respectively.

\section{Results}

\subsection{Benchmark results}

Table III presents the benchmark results regarding the impact of the upstream FDI on the export quality. First, we list upfdi_s and upfdi_m separately in columns (1) and (2). 
Then, we put both of them together in column (3). Finally, we put the comprehensive upstream FDI ( $u p f d i$ ) in column (4). At the same time, we both present the fixed effect (FE) and random effect (RE) regression result. The results of the Hausman specification test in Table III show that fixed effect regression result is better. Equation (1) is estimated via a fixed effects regression model. The results of the Hausman specification test validate our econometric choice. As reported in columns (1) and (3), the coefficient of upfdi_s is positive and significant at the $10 \%$ and $5 \%$ levels, indicating that upstream service FDI tends to increase the export quality of the enterprises. However, in columns (2) and (3), we find the coefficient of upfdi_m is not significant. One possible interpretation of this finding is that compared with manufacturing, service requires much more technology and knowledge, and the differentiation provided by services is stronger. As an important input, services can provide much more variety to downstream enterprises in terms of intermediaries. Therefore, product-service innovation is an input that plays a critical role for manufacturing enterprises (Baines et al., 2017). This is particular important in R\&D-intensive industries (Bustinza et al., 2017a), where from R\&D design to production schedule coordination, more and more enterprises are developing vertical and horizontal linkages to manage the production of products and services. Product-service innovation has become a competitive factor for manufacturing enterprises, which improves the enterprises' export quality. In addition, there will be strong technology spillover not only to the horizontal industries but also to the vertical industries (Baltabaev, 2014; Du et al., 2012; Liu et al., 2009), decreasing the cost of the downstream enterprises, and it is helpful for upgrading export quality. What also needs to be considered is that, according to the statistics from the China Customs Database, the ratio of FDI in manufacturing engaged in processing trade was almost to $80 \%$ in 2007 . This means that manufacturing FDI as an input will have very little impact on downstream enterprises. This is because processing trade is inclined to import more and export more; it relies much more on the foreign market and has almost no relationship with domestic enterprises. In general, the upstream service FDI has a strong positive effect on export quality while the upstream manufacturing FDI has no effect. 
We also find that the coefficient of upfdi in column (4) is not significant. This phenomenon can be explained by the structure of the manufacturing and service FDI in China. Although China entered the WTO in 2001, the country is still very limited in terms of openness of the service industry, and FDI is primarily in the manufacturing sector. The average FDI in the manufacturing sector accounts for $51.45 \%$ while the average FDI in the service industry accounts for only $19.90 \%$. More specifically, some of the manufacturing industries' FDI ratios are over 50\%, including the stationery and sporting equipment manufacturing industry (67\%), communication equipment, computer, and other electronic equipment manufacturing industries (65\%), the leather, fur, and feather products industry (57\%), and the furniture manufacturing industry $(51 \%)$. The tobacco industry $(0 \%)$ and petroleum processing, coking, and nuclear fuel processing industries $(7 \%)$ have a relative low FDI ratio because of the high protection. Comparatively speaking, the proportion of FDI in the service industry is much lower. In the past five years, higher utilization of FDI is found in the accommodation and catering industries $(6 \%)$ and transportation, warehousing, and postal services $(3 \%){ }^{2}$ The uneven distribution of FDI in the industry leads to the insignificant effect of comprehensive upstream FDI on export quality. These results support our hypothesis.

As for the control variables, such as total factor productivity $\left(t f p_{-} l p\right)$, profit rate (ln_profit), financing constraint (ln_finance), the firm's scale (ln_size), and the age of the firm (ln_age), the estimated coefficients are positive and significant at the $1 \%$ level. The higher the enterprise's productivity and profit rate, the easier the financing, the larger the enterprise's scale and the longer the existence in the market, the more help to improve the export quality of the enterprise. This result is consistent with prior research on self-selection mechanisms in which more productive firms are more likely to be successful exporters (Gomes et al., 2018; Melitz, 2003). The coefficient of dummy state is not significant, indicating that export quality is not related to the ownership of the enterprises.

Table III. Impact of the upstream FDI on export quality: benchmark results

\footnotetext{
${ }^{2}$ Source: China Statistical Yearbook and China Industry Economy Statistical Yearbook from 2003 - 2007.
} 


\begin{tabular}{|c|c|c|c|c|c|c|c|c|}
\hline & \multicolumn{2}{|l|}{$(1)$} & \multicolumn{2}{|l|}{ (2) } & \multicolumn{2}{|l|}{ (3) } & \multicolumn{2}{|l|}{ (4) } \\
\hline & $\mathrm{FE}$ & $\mathrm{RE}$ & $\mathrm{FE}$ & $\mathrm{RE}$ & $\mathrm{FE}$ & $\mathrm{RE}$ & $\mathrm{FE}$ & $\mathrm{RE}$ \\
\hline \multirow[t]{2}{*}{ upfdi_s } & $1.915^{*}$ & $1.439^{*}$ & & & $2.335^{* *}$ & $1.636^{*}$ & & \\
\hline & $(1.82)$ & $(1.92)$ & & & $(2.21)$ & (1.86) & & \\
\hline \multirow[t]{2}{*}{ upfdi_m } & & & -0.064 & -0.029 & -0.090 & -0.045 & & \\
\hline & & & $(-1.16)$ & $(-0.64)$ & $(-1.61)$ & $(-1.00)$ & & \\
\hline \multirow[t]{2}{*}{ upfdi } & & & & & & & -0.058 & -0.025 \\
\hline & & & & & & & $(-1.06)$ & $(-0.56)$ \\
\hline \multirow[t]{2}{*}{ tfp_lp } & $0.020 * * *$ & $0.006 * * *$ & $0.020 * * *$ & $0.006 * * *$ & $0.020 * * *$ & $0.006^{* * *}$ & $0.020 * * *$ & $0.006 * * *$ \\
\hline & (14.72) & $(9.78)$ & $(14.70)$ & $(9.77)$ & (14.73) & (9.79) & (14.70) & $(9.77)$ \\
\hline \multirow[t]{2}{*}{ ln_profit } & $0.023 * * *$ & $0.019 * * *$ & $0.023 * * *$ & $0.019 * * *$ & $0.023 * * *$ & $0.019 * * *$ & $0.023 * * *$ & $0.019 * * *$ \\
\hline & (2.79) & $(3.58)$ & $(2.80)$ & $(3.60)$ & $(2.80)$ & $(3.59)$ & $(2.80)$ & $(3.60)$ \\
\hline \multirow[t]{2}{*}{ ln_finance } & $0.019 * * *$ & $0.017 * * *$ & $0.019 * * *$ & $0.017 * * *$ & $0.019 * * *$ & $0.017 * * *$ & $0.019 * * *$ & $0.017 * * *$ \\
\hline & (2.94) & (5.18) & (2.97) & $(5.20)$ & (2.93) & (5.18) & $(2.97)$ & $(5.20)$ \\
\hline \multirow[t]{2}{*}{ ln_size } & $0.031 * * *$ & $0.009 * * *$ & $0.031 * * *$ & $0.009 * * *$ & $0.031 * * *$ & $0.009 * * *$ & $0.031 * * *$ & $0.009^{* * *}$ \\
\hline & (13.94) & (13.52) & (13.92) & (13.52) & (13.92) & (13.52) & (13.92) & (13.52) \\
\hline \multirow[t]{2}{*}{ ln_age } & $0.019 * * *$ & $0.007 * * *$ & $0.019 * * *$ & $0.007 * * *$ & $0.019 * * *$ & $0.007 * * *$ & $0.019 * * *$ & $0.007 * * *$ \\
\hline & $(7.00)$ & $(9.25)$ & $(7.00)$ & $(9.25)$ & (6.98) & $(9.26)$ & $(7.00)$ & $(9.25)$ \\
\hline \multirow[t]{2}{*}{ state } & -0.015 & $-0.016^{* * *}$ & -0.015 & $-0.016^{* * *}$ & -0.016 & $-0.016^{* * *}$ & -0.015 & $-0.016^{* * *}$ \\
\hline & $(-1.05)$ & $(-6.54)$ & $(-1.04)$ & $(-6.54)$ & $(-1.07)$ & $(-6.56)$ & $(-1.04)$ & $(-6.54)$ \\
\hline \multirow[t]{2}{*}{ _cons } & $0.212 * * *$ & $0.471 * * *$ & $0.243 * * *$ & $0.491 * * *$ & $0.223 * * *$ & $0.476 * * *$ & $0.243 * * *$ & $0.490 * * *$ \\
\hline & $(5.27)$ & $(42.21)$ & (6.11) & $(50.94)$ & $(5.44)$ & (36.96) & (6.09) & $(49.24)$ \\
\hline Year & Yes & Yes & Yes & Yes & Yes & Yes & Yes & Yes \\
\hline Industry & Yes & Yes & Yes & Yes & Yes & Yes & Yes & Yes \\
\hline Province & Yes & Yes & Yes & Yes & Yes & Yes & Yes & Yes \\
\hline Obs. & 111520 & 111520 & 111520 & 111520 & 111520 & 111520 & 111520 & 111520 \\
\hline $\begin{array}{l}\text { Adjusted } \\
\mathrm{R}^{2}\end{array}$ & 0.013 & 0.028 & 0.013 & 0.028 & 0.013 & 0.028 & 0.013 & 0.028 \\
\hline Hausman & & 6.17 & & 14.76 & & 18.45 & & 14.64 \\
\hline test & & $.00)$ & & $.00)$ & & $.00)$ & & $.00)$ \\
\hline
\end{tabular}

Note: $t$ statistics based on clustered robust standard errors are reported in parentheses. ***, **, and * denote significant at the $1 \%, 5 \%$, and $10 \%$ levels, respectively.

\subsection{Sub-sample estimation according to the manufacturing industries with different service intensity}

Based on the analysis above, the effect of the upstream FDI on the export quality of manufacturing enterprises primarily relies on the dependence of one to the other. We 
investigate the different dependence relationships from the service intensity of the downstream manufacturing enterprises, conducting a sub-sample test using service intensity. Crozet and Milet (2017) classified higher industry service intensity in these three specific manufacturing groups: Group 1 is composed of wood product and paper manufacturing sectors (NAICS codes 21, 22); Group 2 is comprised of plastic, rubber product, and non-metallic mineral product manufacturing sectors (NAICS codes 26, 27); and Group 3 includes primary metal manufacturing, fabricated metal product manufacturing, machinery manufacturing, computer and electronic product manufacturing, and electrical equipment, appliance, and component manufacturing sectors (NAICS codes 31, 32, 33, 34, 35). Data from the ORBIS datasets confirm that most of the manufacturing sectors in China with higher industry service intensity are included in Crozet and Milet's classification, but with slight differences. While higher service intensity is found in Group 3 (23.46\% service intensity on average) and Group 2 (15.84\%), Group 1 is at 9.79\% service intensity. This percentage is below the $14.51 \%$ of textile mills, textile product mills, apparel manufacturing, and leather and allied product manufacturing (NAICS codes 13, 14, 15, 16). Therefore, we exchange Group 1 from Crozet and Millet (2017) for a new group more suitable for the Chinese context: textile mills, textile product mills, apparel manufacturing, and leather and allied product manufacturing, NAICS codes 13, 14, 15, 16 (15.84\%). Interestingly, this manufacturing sector classification is in line with previous studies about manufacturing servitization in China ( $\mathrm{Li}$ et al., 2015). Therefore, we define all of the manufacturing industries above as high service-intensive (53.81\%). As for low service-intensive industries sectors (46.19\%): petroleum and coal products manufacturing, and chemical manufacturing, NAICS codes 24, 25 (10.84\%), wood product manufacturing, and paper manufacturing sectors, NAICS codes 21, 22 (9.89\%); wood product and paper manufacturing sectors, NAICS codes 21, 22 (9.79\%); transportation equipment manufacturing, NAICS code 36 (6.46\%); food manufacturing, and beverage and tobacco product manufacturing, NAICS codes 11, $12(5.31 \%)$; furniture and related product manufacturing and miscellaneous manufacturing, NAICS code 37, 39 (3.9\%). 
In order to investigate the different impacts of upstream FDI on the export quality of enterprises within different service-intensive industries, we use the sub-sample of the high and low service-intensive industry to do the estimation. Table IV presents the results. For the upstream service FDI, we find that it has a much larger positive effect on the export quality of enterprises only within the high service-intensive industry, as the coefficient of $f d i_{-} s$ in the high service-intensive industry is significant. A possible explanation is that, compared to the low service-intensive industry, the high service-intensive industry is more dependent on specific services, such as IT, engineering, or business consulting (Gomes et al., 2017). Product-service innovation facilitates updating product lifecycle, increases supply quality, and develops barriers to imitation (Bustinza et al., 2017b). Thus, upstream service FDI will greatly improve the export quality of these enterprises. Both the upstream manufacturing FDI and the comprehensive upstream FDI, like the benchmark results, are insignificant in the high service-intensive and low service-intensive industries. As for other control variables, there is no significant change as compared with the benchmark results.

Table IV. Impact of the upstream FDI on export quality: sub-sample with different service

\begin{tabular}{|c|c|c|c|c|c|c|c|c|}
\hline & \multicolumn{4}{|c|}{ High service-intensity industry } & \multicolumn{4}{|c|}{ Low service-intensity industry } \\
\hline & (1) & (2) & (3) & (4) & (5) & (6) & (7) & (8) \\
\hline \multirow[t]{2}{*}{ fdi_s } & $8.224 * * *$ & & $8.327 * * *$ & & 0.736 & & 0.879 & \\
\hline & $(3.86)$ & & (3.54) & & $(0.57)$ & & $(0.68)$ & \\
\hline \multirow[t]{2}{*}{ fdi_m } & & -0.113 & 0.021 & & & -0.014 & -0.025 & \\
\hline & & $(-0.75)$ & $(0.13)$ & & & $(-0.22)$ & $(-0.39)$ & \\
\hline \multirow[t]{2}{*}{ fdi } & & & & -0.089 & & & & -0.012 \\
\hline & & & & $(-0.57)$ & & & & $(-0.19)$ \\
\hline \multirow[t]{2}{*}{ tfp_lp } & $0.018 * * *$ & $0.017 * * *$ & $0.018 * * *$ & $0.017 * * *$ & $0.023 * * *$ & $0.023 * * *$ & $0.023 * * *$ & $0.023^{* * *}$ \\
\hline & $(9.42)$ & $(9.31)$ & $(9.42)$ & $(9.31)$ & $(11.42)$ & $(11.42)$ & $(11.42)$ & $(11.42)$ \\
\hline \multirow[t]{2}{*}{ ln_profit } & $0.020^{* *}$ & $0.021^{* *}$ & $0.020 * *$ & $0.021 * *$ & $0.027 *$ & $0.027 *$ & $0.027 *$ & $0.027 *$ \\
\hline & $(2.20)$ & $(2.23)$ & $(2.20)$ & $(2.23)$ & $(1.85)$ & $(1.85)$ & $(1.85)$ & $(1.85)$ \\
\hline \multirow[t]{2}{*}{ ln_finance } & $0.023^{* * *}$ & $0.024 * * *$ & $0.023 * * *$ & $0.024 * * *$ & 0.014 & 0.014 & 0.014 & 0.014 \\
\hline & (2.87) & $(2.95)$ & (2.87) & $(2.95)$ & $(1.37)$ & $(1.37)$ & $(1.36)$ & (1.37) \\
\hline \multirow[t]{2}{*}{ ln_size } & $0.028^{* * *}$ & $0.027^{* * *}$ & $0.028 * * *$ & $0.027 * * *$ & $0.033 * * *$ & $0.033^{* * *}$ & $0.033^{* * *}$ & $0.033^{* * *}$ \\
\hline & $(8.75)$ & $(8.69)$ & $(8.74)$ & (8.69) & (10.48) & (10.47) & (10.48) & (10.47) \\
\hline
\end{tabular}




\begin{tabular}{|c|c|c|c|c|c|c|c|c|}
\hline \multirow[t]{2}{*}{ ln_age } & $0.015 * * *$ & $0.015 * * *$ & $0.015 * * *$ & $0.015 * * *$ & $0.024 * * *$ & $0.024 * * *$ & $0.024 * * *$ & $0.024 * * *$ \\
\hline & (3.79) & $(3.84)$ & (3.79) & $(3.84)$ & $(6.32)$ & $(6.31)$ & $(6.31)$ & $(6.32)$ \\
\hline \multirow[t]{2}{*}{ state } & -0.008 & -0.008 & -0.008 & -0.008 & -0.021 & -0.021 & -0.022 & -0.021 \\
\hline & $(-0.39)$ & $(-0.37)$ & $(-0.39)$ & $(-0.37)$ & $(-1.00)$ & $(-1.00)$ & $(-1.01)$ & $(-0.99)$ \\
\hline \multirow[t]{2}{*}{ _cons } & $0.246 * * *$ & $0.276^{* * *}$ & $0.242 * * *$ & $0.272 * * *$ & $0.213 * * *$ & $0.223 * * *$ & $0.216 * * *$ & $0.223 * * *$ \\
\hline & $(6.48)$ & $(5.98)$ & $(5.02)$ & $(5.83)$ & (4.38) & $(4.63)$ & $(4.36)$ & $(4.61)$ \\
\hline Year & Yes & Yes & Yes & Yes & Yes & Yes & Yes & Yes \\
\hline Industry & Yes & Yes & Yes & Yes & Yes & Yes & Yes & Yes \\
\hline Province & Yes & Yes & Yes & Yes & Yes & Yes & Yes & Yes \\
\hline Obs. & 60609 & 60609 & 60609 & 60609 & 50911 & 50911 & 50911 & 50911 \\
\hline Adjusted $\mathrm{R}^{2}$ & 0.011 & 0.011 & 0.011 & 0.011 & 0.015 & 0.015 & 0.015 & 0.015 \\
\hline
\end{tabular}

Note: $t$ statistics based on clustered robust standard errors are reported in parentheses. $* * *, * *$, and $*$ denote significant at the $1 \%, 5 \%$, and $10 \%$ levels, respectively.

Because the estimation results above come from different sub-samples, the robustness of these conclusions is not certain. Thus, the Chow test is conducted for confirmation. Here we introduce a dummy variable for the service-intensive industry (Serv_intensity). If the enterprise is in the high service-intensive industry, then Serv_intensity $=1$, or Serv_intensity $=0$ otherwise. In order to investigate the different impact of the upstream FDI on the export quality of enterprises within different service-intensive industries, we add the interaction term of upstream service (manufacturing and comprehensive) FDI and service intensity of the industry into the regression separately. The null hypothesis (H0) of the Chow Test is as follow: the coefficient of the interaction term is 0 . The estimation results are presented in Table V. We find that only the coefficient of the interaction term of upstream service FDI and service intensity of the industry (upfdi_s*Serv_intensity) is positive and significant on the 5\% level. This rejects the null hypothesis, which indicates that upstream service FDI has a much larger positive effect on the export quality of enterprises within the high service-intensive industry while the upstream manufacturing and comprehensive FDI do not have a significant effect on the export quality of the enterprises regardless of whether a high service-intensive or low service-intensive industry. Therefore, the conclusions of the sub-sample regression results are robust. 
Table V. Impact of the upstream FDI on the export quality of enterprise with different service intensity: Chow test

\begin{tabular}{|c|c|c|c|c|}
\hline & (1) & (2) & (3) & (4) \\
\hline \multirow[t]{2}{*}{ upfdi_s } & 0.981 & & 1.449 & \\
\hline & $(0.81)$ & & $(1.18)$ & \\
\hline \multirow[t]{2}{*}{ upfdi_s*Serv_intensity } & $4.256 * *$ & & $5.980 * *$ & \\
\hline & $(2.89)$ & & $(2.27)$ & \\
\hline \multirow[t]{2}{*}{ upfdi_m } & & -0.066 & -0.090 & \\
\hline & & $(-1.19)$ & $(-1.60)$ & \\
\hline \multirow[t]{2}{*}{ upfdi_m*Serv_intensity } & & 0.063 & 0.215 & \\
\hline & & $(0.60)$ & $(0.71)$ & \\
\hline \multirow[t]{2}{*}{ upfdi } & & & & -0.061 \\
\hline & & & & $(-1.10)$ \\
\hline \multirow[t]{2}{*}{ upfdi*Serv_intensity } & & & & 0.075 \\
\hline & & & & $(0.69)$ \\
\hline \multirow[t]{2}{*}{ Serv_intensity } & 0.010 & 0.005 & -0.014 & 0.005 \\
\hline & $(0.18)$ & $(0.09)$ & $(-0.24)$ & $(0.09)$ \\
\hline \multirow[t]{2}{*}{ tfp_lp } & $0.022 * * *$ & $0.021 * * *$ & $0.022 * * *$ & $0.021 * * *$ \\
\hline & $(16.03)$ & (15.97) & $(16.05)$ & (15.97) \\
\hline \multirow[t]{2}{*}{ ln_profit } & $0.000 * * *$ & $0.000 * * *$ & $0.000 * * *$ & $0.000 * * *$ \\
\hline & $(33.90)$ & $(25.53)$ & $(21.54)$ & $(25.02)$ \\
\hline \multirow[t]{2}{*}{ ln_finance } & $0.010 * * *$ & $0.010 * * *$ & $0.010 * * *$ & $0.010 * * *$ \\
\hline & $(2.90)$ & $(2.91)$ & $(2.90)$ & $(2.91)$ \\
\hline \multirow[t]{2}{*}{ ln_size } & $0.031 * * *$ & $0.031 * * *$ & $0.031 * * *$ & $0.031 * * *$ \\
\hline & $(14.24)$ & $(14.14)$ & (14.18) & $(14.14)$ \\
\hline \multirow[t]{2}{*}{ ln_age } & $0.019 * * *$ & $0.019 * * *$ & $0.019 * * *$ & $0.019 * * *$ \\
\hline & $(6.81)$ & $(6.86)$ & $(6.81)$ & $(6.86)$ \\
\hline \multirow[t]{2}{*}{ state } & -0.016 & -0.016 & -0.016 & -0.016 \\
\hline & $(-1.07)$ & $(-1.07)$ & $(-1.10)$ & $(-1.07)$ \\
\hline \multirow[t]{2}{*}{ _cons } & $0.208 * * *$ & $0.232 * * *$ & $0.220 * * *$ & $0.232 * * *$ \\
\hline & $(5.12)$ & $(5.83)$ & $(5.34)$ & $(5.81)$ \\
\hline Year & Yes & Yes & Yes & Yes \\
\hline Industry & Yes & Yes & Yes & Yes \\
\hline Province & Yes & Yes & Yes & Yes \\
\hline Obs. & 111722 & 111722 & 111722 & 111722 \\
\hline Adjusted $\mathrm{R}^{2}$ & 0.013 & 0.013 & 0.013 & 0.013 \\
\hline
\end{tabular}




\subsection{Robust check: Heckman regression results}

In the previous sections, we simply selected the export firm as the sample to estimate the impact of upstream FDI on the export quality of the downstream manufacturing firm. However, this may lead to a sample selection problem, which will lead to bias in the empirical results. In this part, we will use the Heckman two-stage model (Heckman, 1979) to overcome this problem. First, we should calculate the mills lambda by estimate the export probability with the Probit model. Following most literature (Bernard and Jensen, 2004; Feenstra et al., 2014; Melitz, 2003), we choose seven variables reflecting the enterprises' characteristics to estimate the export probability: total factor productivity $\left(t f p_{-} l p\right)$, profit rate (profit), financing constraint (finance), enterprise scale (ln_size), age of the enterprise (ln_age), ratio of capital over labour (ln_capital), and ownership of the enterprise (State). Then, we make the second stage regression, putting the mills lambda back into the basic regression model. The empirical results for the entire sample and the sub-sample are presented in Tables VI and VII, respectively.

In Table VI, we can find that mills lambda is significant in the $1 \%$ level, indicating that the sample selection problem truly exists, and we use the Heckman two-stage model to do the regression as necessary. Meanwhile, the estimation results are the same as the benchmark results, with no obvious differences. That is, the upstream service FDI helps to improve the export quality of the downstream enterprises while the upstream manufacturing FDI and comprehensive upstream FDI are uncertain.

As for the Probit regression result, the estimated coefficients of the total factor productivity ( $\left.t f p_{-} l p\right)$, profit rate (profit), financing constraint (finance), enterprise scale (ln_size), age of the enterprise (ln_age), and capital intensity (ln_capital) are positive and almost significant at the $1 \%$ level. This indicates that the enterprises have greater productivity, a higher profit rate, easier financing, a larger scale, a longer existence in the 
market and more capital intensive, then they are more likely to export. The coefficient of the dummy state is negative and significant, indicating that non-state-owned enterprises are more likely to export because of the low productivity of state-owned enterprises (Yu, 2015).

Table VI. Robustness check: Heckman regression results

\begin{tabular}{|c|c|c|c|c|}
\hline & (1) & (2) & (3) & (4) \\
\hline upfdi_s & $\begin{array}{l}1.441 * \\
(1.88)\end{array}$ & & $\begin{array}{l}1.625 * * \\
(2.08)\end{array}$ & \\
\hline upfdi_m & & $\begin{array}{l}-0.026 \\
(-0.71)\end{array}$ & $\begin{array}{l}-0.042 \\
(-1.13)\end{array}$ & \\
\hline upfdi & & & & $\begin{array}{l}-0.022 \\
(-0.62)\end{array}$ \\
\hline tfp_lpva & $\begin{array}{l}0.007 * * * \\
(10.14)\end{array}$ & $\begin{array}{l}0.007 * * * \\
(10.13)\end{array}$ & $\begin{array}{l}0.007 * * * \\
(10.14)\end{array}$ & $\begin{array}{l}0.007 * * * \\
(10.13)\end{array}$ \\
\hline ln_profit & $\begin{array}{l}0.019 * * * \\
(4.53)\end{array}$ & $\begin{array}{l}0.019 * * * \\
(4.54)\end{array}$ & $\begin{array}{l}0.019 * * * \\
(4.54)\end{array}$ & $\begin{array}{l}0.019 * * * \\
(4.54)\end{array}$ \\
\hline ln_finance & $\begin{array}{l}0.017 * * * \\
(5.38)\end{array}$ & $\begin{array}{l}0.017 * * * \\
(5.39)\end{array}$ & $\begin{array}{l}0.017 * * * \\
(5.37)\end{array}$ & $\begin{array}{l}0.017 * * * \\
(5.39)\end{array}$ \\
\hline ln_size & $\begin{array}{l}0.009 * * * \\
(7.16)\end{array}$ & $\begin{array}{l}0.009 * * * \\
(7.15)\end{array}$ & $\begin{array}{l}0.009 * * * \\
(7.15)\end{array}$ & $\begin{array}{l}0.009 * * * \\
(7.15)\end{array}$ \\
\hline ln_age & $\begin{array}{l}0.007 * * * \\
(9.23)\end{array}$ & $\begin{array}{l}0.007 * * * \\
(9.22)\end{array}$ & $\begin{array}{l}0.007 * * * \\
(9.22)\end{array}$ & $\begin{array}{l}0.007 * * * \\
(9.22)\end{array}$ \\
\hline state & $\begin{array}{l}-0.011 * * * \\
(-4.78)\end{array}$ & $\begin{array}{l}-0.011^{* * *} \\
(-4.76)\end{array}$ & $\begin{array}{l}-0.011^{* * *} \\
(-4.80)\end{array}$ & $\begin{array}{l}-0.011 * * * \\
(-4.76)\end{array}$ \\
\hline _cons & $\begin{array}{l}0.450 * * * \\
(23.01)\end{array}$ & $\begin{array}{l}0.469 * * * \\
(24.98)\end{array}$ & $\begin{array}{l}0.455^{* * *} \\
(22.71)\end{array}$ & $\begin{array}{l}0.469 * * * \\
(24.82)\end{array}$ \\
\hline Year & Yes & Yes & Yes & Yes \\
\hline Industry & Yes & Yes & Yes & Yes \\
\hline Province & Yes & Yes & Yes & Yes \\
\hline $\begin{array}{l}\text { mills } \\
\text { lambda }\end{array}$ & $\begin{array}{l}0.006 * \\
(1.85)\end{array}$ & $\begin{array}{l}0.006 * \\
(1.84)\end{array}$ & $\begin{array}{l}0.006 * \\
(1.86)\end{array}$ & $\begin{array}{l}0.006 * \\
(1.84)\end{array}$ \\
\hline Obs. & 1016770 & 1016770 & 1016770 & 1016770 \\
\hline
\end{tabular}

Note: $t$ statistics based on clustered robust standard errors are reported in parentheses. $* * *, * *$, and $*$ denote significant at the $1 \%, 5 \%$, and $10 \%$ levels, respectively.

The sub-sample Heckman two-stage model regression results are presented in Table VII. The estimation results also indicate that the upstream service FDI improve the export quality of the firm in the high service-intensive industry much more than in the low service-intensive 
industry. The upstream manufacturing FDI and the comprehensive upstream FDI are both insignificant. Other control variables and statistics demonstrate no obvious change. Therefore, our hypotheses are supported and are not affected by the sample selection problem. The conclusions are robust.

Table VII. Robust check: Heckman regression sub-sample with different service

\begin{tabular}{|c|c|c|c|c|c|c|c|c|}
\hline & $\begin{array}{l}\text { (1) } \\
\text { High servic }\end{array}$ & $\begin{array}{l}\text { (2) } \\
\text { intensity in }\end{array}$ & $\begin{array}{l}\text { (3) } \\
\text { dustry }\end{array}$ & (4) & $\begin{array}{l}\text { (5) } \\
\text { Low servic }\end{array}$ & $\begin{array}{l}\text { (6) } \\
\text { intensity in }\end{array}$ & $\begin{array}{l}\text { (7) } \\
\text { ustry }\end{array}$ & (8) \\
\hline upfdi_s & $\begin{array}{l}4.225 * * * \\
(2.58)\end{array}$ & & $\begin{array}{l}4.014 * * \\
(2.36)\end{array}$ & & $\begin{array}{l}1.009 \\
(1.09)\end{array}$ & & $\begin{array}{l}1.012 \\
(1.05)\end{array}$ & \\
\hline upfdi_m & & $\begin{array}{l}-0.106 \\
(-1.14)\end{array}$ & $\begin{array}{l}-0.043 \\
(-0.45)\end{array}$ & & & $\begin{array}{l}0.012 \\
(0.27)\end{array}$ & $\begin{array}{l}-0.001 \\
(-0.01)\end{array}$ & \\
\hline upfdi & & & & $\begin{array}{l}-0.095 \\
(-1.01)\end{array}$ & & & & $\begin{array}{l}0.013 \\
(0.32)\end{array}$ \\
\hline tfp_lpva & $\begin{array}{l}0.005^{* * *} \\
(5.87)\end{array}$ & $\begin{array}{l}0.005^{* * *} \\
(5.84)\end{array}$ & $\begin{array}{l}0.005^{* * * *} \\
(5.87)\end{array}$ & $\begin{array}{l}0.005 * * * \\
(5.84)\end{array}$ & $\begin{array}{l}0.009 * * * \\
(8.72)\end{array}$ & $\begin{array}{l}0.009 * * * \\
(8.71)\end{array}$ & $\begin{array}{l}0.009 * * * \\
(8.72)\end{array}$ & $\begin{array}{l}0.009 * * * \\
(8.71)\end{array}$ \\
\hline ln_profit & $\begin{array}{l}0.020 * * * \\
(4.00)\end{array}$ & $\begin{array}{l}0.021 * * * \\
(4.01)\end{array}$ & $\begin{array}{l}0.021 * * * \\
(4.00)\end{array}$ & $\begin{array}{l}0.021 * * * \\
(4.01)\end{array}$ & $\begin{array}{l}0.018^{* *} \\
(2.33)\end{array}$ & $\begin{array}{l}0.018^{* * *} \\
(2.34)\end{array}$ & $\begin{array}{l}0.018^{* *} \\
(2.33)\end{array}$ & $\begin{array}{l}0.018^{* *} \\
(2.34)\end{array}$ \\
\hline ln_finance & $\begin{array}{l}0.022 * * * \\
(4.80)\end{array}$ & $\begin{array}{l}0.022 * * * \\
(4.82)\end{array}$ & $\begin{array}{l}0.022 * * * \\
(4.80)\end{array}$ & $\begin{array}{l}0.022 * * * \\
(4.82)\end{array}$ & $\begin{array}{l}0.012 * * * \\
(2.66)\end{array}$ & $\begin{array}{l}0.012 * * * \\
(2.67)\end{array}$ & $\begin{array}{l}0.012 * * * \\
(2.66)\end{array}$ & $\begin{array}{l}0.012 * * * \\
(2.67)\end{array}$ \\
\hline ln_size & $\begin{array}{l}0.009 * * * \\
(4.49)\end{array}$ & $\begin{array}{l}0.009 * * * \\
(4.46)\end{array}$ & $\begin{array}{l}0.009 * * * \\
(4.49)\end{array}$ & $\begin{array}{l}0.009 * * * \\
(4.46)\end{array}$ & $\begin{array}{l}0.009 * * * \\
(5.43)\end{array}$ & $\begin{array}{l}0.009 * * * \\
(5.44)\end{array}$ & $\begin{array}{l}0.009 * * * \\
(5.43)\end{array}$ & $\begin{array}{l}0.009 * * * \\
(5.44)\end{array}$ \\
\hline ln_age & $\begin{array}{l}0.006^{* * *} \\
(6.09)\end{array}$ & $\begin{array}{l}0.006^{* * *} \\
(6.09)\end{array}$ & $\begin{array}{l}0.006^{* * * *} \\
(6.09)\end{array}$ & $\begin{array}{l}0.006 * * * \\
(6.09)\end{array}$ & $\begin{array}{l}0.008^{* * * *} \\
(6.77)\end{array}$ & $\begin{array}{l}0.008 * * * \\
(6.77)\end{array}$ & $\begin{array}{l}0.008^{* * *} \\
(6.77)\end{array}$ & $\begin{array}{l}0.008^{* * * *} \\
(6.77)\end{array}$ \\
\hline state & $\begin{array}{l}-0.011 * * * \\
(-3.64)\end{array}$ & $\begin{array}{l}-0.011 * * * \\
(-3.58)\end{array}$ & $\begin{array}{l}-0.011 * * * \\
(-3.64)\end{array}$ & $\begin{array}{l}-0.011 * * * \\
(-3.58)\end{array}$ & $\begin{array}{l}-0.010^{* * *} \\
(-2.81)\end{array}$ & $\begin{array}{l}-0.010 * * * \\
(-2.79)\end{array}$ & $\begin{array}{l}-0.010^{* * * *} \\
(-2.81)\end{array}$ & $\begin{array}{l}-0.010 * * * \\
(-2.79)\end{array}$ \\
\hline _cons & $\begin{array}{l}0.492 * * * \\
(20.00)\end{array}$ & $\begin{array}{l}0.518^{* * *} \\
(17.39)\end{array}$ & $\begin{array}{l}0.501 * * * \\
(16.35)\end{array}$ & $\begin{array}{l}0.516^{* * * *} \\
(17.21)\end{array}$ & $\begin{array}{l}0.440 * * * \\
(16.18)\end{array}$ & $\begin{array}{l}0.448 * * * \\
(16.99)\end{array}$ & $\begin{array}{l}0.440 * * * \\
(16.00)\end{array}$ & $\begin{array}{l}0.448 * * * \\
(16.93)\end{array}$ \\
\hline Year & Yes & Yes & Yes & Yes & Yes & Yes & Yes & Yes \\
\hline Industry & Yes & Yes & Yes & Yes & Yes & Yes & Yes & Yes \\
\hline Province & Yes & Yes & Yes & Yes & Yes & Yes & Yes & Yes \\
\hline $\begin{array}{l}\text { mills } \\
\text { lambda }\end{array}$ & $\begin{array}{l}0.005^{*} \\
(1.86)\end{array}$ & $\begin{array}{l}0.005^{*} \\
(1.85)\end{array}$ & $\begin{array}{l}0.005^{*} \\
(1.84)\end{array}$ & $\begin{array}{l}0.005^{*} \\
(1.85)\end{array}$ & $\begin{array}{l}0.005 * \\
(1.87)\end{array}$ & $\begin{array}{l}0.005^{*} \\
(1.84)\end{array}$ & $\begin{array}{l}0.005^{*} \\
(1.86)\end{array}$ & $\begin{array}{l}0.005^{*} \\
(1.85)\end{array}$ \\
\hline Observations & 621300 & 621300 & 621300 & 621300 & 395470 & 395470 & 395470 & 395470 \\
\hline
\end{tabular}

\section{Discussion and conclusion}




\subsection{Theoretical contributions}

This study makes three theoretical contributions by (1) clarifying the concept of international marketing agility by offering theoretical underpinnings from standardization and adaptation marketing literature; (2) investigating the influence of upstream FDI intensity on export quality while taking into account the manufacturing and service industry contexts; and (3) providing an enhanced understanding of the impact of service intensity of manufacturing firms on export quality. First, our research contributes to a nuanced understanding of international marketing agility by juxtaposing the standardization and adaptation marketing literature with capability literature. The previous research on agility tends to focus on strategic aspects such as strategic agility without paying sufficient attention to the international marketing contexts. Our findings suggest the international marketing literature, especially standardization and adaptation (Tan and Sousa, 2013), may offer important theoretical underpinnings to understanding international marketing agility. In so doing, our study extends the recent discussion on agility by connecting agility as an organizational capability perspective with international marketing literature. In addition, our findings offer further insights into international marketing agility by highlighting that agility can be understood beyond the conventional approach in studying strategic agility. Thus, we propose that international marketing agility is a specific strategic agility that can be defined as the ability of organizations to swiftly apply marketing practices contingent upon domestic and international market situations.

Second, our findings shed light on the understanding of international marketing agility in industry contexts, especially through a comparative lens of the manufacturing and service industries. By highlighting the industry contexts, the role of international marketing agility can be understood by taking into account the contextual factors, and the development of international marketing agility is associated with the industry characteristics in international contexts. By distinguishing between the service and manufacturing industries, our findings suggest that the influence of FDI intensity on export quality differs depending upon the industry contexts. The closer relationship and interactions between upstream FDI and companies in the service industry demand the downstream companies to develop the agile 
capability to serve international customers. Thus, international marketing agility is conducive to higher export quality in the service industry. In contrast, the standardized production found in manufacturing industries does not require higher flexibility, thus not contributing to the development of international marketing agility. Therefore, export quality in the manufacturing industry tends to be weaker than in the service industry. In so doing, our research contributes to advancing the understanding of international marketing agility in different industry contexts, especially by underscoring the different influences of upstream FDI on export quality from a comparative perspective.

Third, our study contributes to the servitization literature from an international marketing perspective. Especially, our study joined the recent studies that have examined the degree of servitization across different manufacturing industry sectors (Crozet and Milet, 2017) and to what extent service intensity may affect performance. Our study shows that contemporaneous strategic management frames and management theories can be effectively used to evaluate organizational phenomena taking place in the Chinese context (Xing and Liu, 2015). Furthermore, these results extrapolate and can be compared to prior work focused on both developed economies and other emerging countries, such as Central and Eastern Europe or Latin America. Our findings also lend further support to recent research that highlights the importance of service intensity. By focusing on different manufacturing sectors, our study offers an enhanced understanding of the role of servitization in international marketing. Specifically, higher service intensity can lead to better export quality. Furthermore, the nuanced understanding derived from our study points to the distinctive characteristics of servitization with regard to gaining competitive advantages in international marketing. This finding also lends support to recent studies showing that service intensity might be applicable to other cultural contexts beyond those found in the West.

\subsection{Managerial and policy implications}

Our research provides managerial and policy implications for policymakers and export firms in both the manufacturing and service industry sectors. First, the types of upstream FDI in emerging economies can significantly affect the performance of downstream firms. It is of 
significant importance to attract upstream FDI in the service industry that may enhance export quality. Attracting upstream FDI in the manufacturing industry contributes marginally to improving export quality. Thus, when the Chinese economy undergoes economic transformation and an upgrading trajectory, policymakers need to pay attention to what types of FDI should be encouraged and retained. Upstream FDI in the service industry may complement the skillsets of and foster the cultivation of international marketing agility by domestic firms.

On the firm level, international marketing agility as an organizational capability can be enhanced through interactions with upstream FDI. The knowledge heterogeneity and knowledge spillover between FDI and domestic firms demand both the motivation and the capability of export firms to learn because effective learning between foreign firms and domestic counterparts tends to require a long-term approach (Collinson and Liu, 2017). Thus, we urge domestic firms to pay sufficient attention to resource allocations and mobilization (Liu and Huang, 2018) so as to build specific organizational capabilities such as international marketing agility. When China interacts more and more closely with the rest of the world, export quality becomes one criterion for shifting the global perception of 'Made in China' to 'Created in China' against the globalizing environment in which Chinese companies interact with customers from other countries. We argue that there are ample opportunities for Chinese export firms to learn from their international counterparts in order to improve international marketing agility, thus enhancing export quality. In addition, we suggest that manufacturing firms add and expand service offerings because service intensity may help to enhance the export quality.

\subsection{Limitations and future research directions}

With this quantitative research, we hope to advance international marketing agility beyond the empirical settings of export quality of Chinese enterprises. There are multiple future research directions for scholars to contribute to this nascent research stream on international marketing agility. First, we suggest comparative analysis on export quality in different national contexts, including both emerging and advanced economies. The export industry is global in nature, 
thus providing the empirical context to validate and further refine the relationship between FDI, service intensity, and export quality derived from our study. There are other dimensions of international marketing agility within other contexts, and a comparative approach holds great promise to further advance research on the subject. Second, our study examines international marketing agility by focusing on standardization and adaptation literature, illuminating the complex interaction between FDI, service intensity, and export quality. Other marketing literature is associated with important concepts and characteristics affecting the conditions, process, and outcomes of international marketing practices. We encourage future research to use pertinent international marketing literature such as brand management (Liu et $a l ., 2017)$ to empirically test the relationship between FDI, service intensity, and performance outcomes so as to further the knowledge base on the consequences of international marketing agility. The vibrant research stream on emerging marketing firms venturing into advanced economies (Liu and Vrontis, 2017) and servitization through acquisitions (Xing et al., 2017) may offer some insights for such scholarly inquiry. The rising phenomenon of emerging market firms' outbound FDI may challenge existing theories and offers some promising research opportunities for advancing the body of knowledge in service, servitization, and international marketing agility. Moreover, we suggest future research can use qualitative research methods to further pursue this line of scholarly inquiry as innovative qualitative research may provide in-depth understanding beyond the limitations of quantitative study.

\subsection{Conclusion}

This paper contributes to the international marketing agility literature by connecting organizational capability literature with standardization and adaptation literature. We investigate the extent to which managing the tension between product standardization and service customization may generate an extra premium in international markets. We develop and test an econometric model by using two Chinese datasets, the Annual Survey of Industrial Enterprises (ASIE) and the China Customs Database. Our findings offer a nuanced understanding of international marketing agility and investigate the complex relationships between FDI, service intensity, and export quality. Our analysis reveals that international 
marketing agility is reached through upstream FDI intensity, particularly in the context of service FDI. Manufacturing sectors with higher service intensity have more agility, being more likely to generate export quality. 


\section{References}

Aitken, B.J. and Harrison A.E. (1999), "Do domestic firms benefit from foreign direct investment? Evidence from panel data", American Economic Review, Vol. 89 No. 3, pp. 605-618.

Altomonte, C. and Pennings E. (2009), "Domestic plant productivity and incremental spillovers from foreign direct investment ", Journal of International Business Studies, Vol. 40 No. 7, pp. 1131-1148.

Amit, K. (2011), "The long and short of quality ladders”, Review of Economics Studies, Vol. 77 No. 4, pp. 1450-1476.

Amiti, M. and Wei, S. (2009), "Service offshoring and productivity: evidence from the United States ", The World Economy, Vol. 32 No. 2, pp. 203-220.

Anderson, E.W., Fornell, C. and Rust, R.T. (1997), "Customer satisfaction, productivity, and profitability: differences between goods and services", Marketing Science, Vol. 16 No. 2, pp. 129-145.

Ariu, A. (2016a), “Crisis-proof services: why trade in services did not suffer during the 20082009 collapse”, Journal of International Economics, Vol. 98, pp. 138-149.

Ariu, A. (2016b), "Services versus goods trade: a firm-level comparison", Review of World Economics, Vol. 152 No. 1, pp-19-41.

Arnold J.M., Javorcik B.S. and Mattoo A. (2011), "The productivity effects of services liberalization evidence from the Czech Republic", Journal of International Economics, Vol. 85 No. 1, pp. 136-146.

Baalbaki, I.B. and Malhotra, N.K. (1993) "Marketing management bases for international market segmentation: an alternate look at the standardization/customization debate", International Marketing Review, Vol. 10 No. 1, pp. 19-44.

Baines, T. and Lightfoot, H. (2013). Made to Serve: How manufacturers can compete through servitization and product service systems. John Wiley \& Sons, Chichester, UK.

Baines, T., Bigdeli, A., Bustinza, O.F., Shi, V., Baldwin, J.S. and Ridgway, K. (2017), "Servitization: revisiting the state-of-the art and research priorities", International Journal of Operations \& Production Management, Vol. 37 No. 2, pp. 256-278. 
Baltabaev, B. (2014), "Foreign direct investment and total factor productivity growth: new macro-evidence", The World Economy, Vol. 37 No. 2, pp. 311-334.

Barrell, R. and Pain, N. (1997), "Foreign direct investment, technological change, and economic growth within Europe", The Economic Journal, Vol. 107 No. 445, pp. $1770-1786$.

Bas, M. and Strauss-Kahn, V. (2015), "Input-trade liberalization, export prices and quality upgrading”, Journal of International Economics, Vol. 95 No. 2, pp. 250-262.

Brannen, M.Y. and Y. L. Doz (2012), "Corporate languages and strategic agility: trapped in your jargon or lost in translation?", California Management Review, Vol. 54 No. 2, pp. 77-97.

Brandt, L., Biesebroeck, J.V. and Zhang, Y. (2012), "Creative accounting or creative destruction? Firm-level productivity growth in Chinese manufacturing", Journal of Development Economics, Vol. 97 No. 2, pp. 339-351.

Brown, S. L. and Eisenhardt, K. M. (1997), "The art of continuous change: linking complexity theory and time-paced evolution in relentlessly shifting organizations", Administrative Science Quarterly, Vol. 42 No. 1, 1-34.

Brueller, N.N., A.Carmeli and I. Drori (2014), "How do different types of mergers and acquisitions facilitate strategic agility?", California Management Review, Vo. 56 No. 3, pp. 39-57.

Bustinza, O.F., Gomes, E., Vendrell-Herrero, F. and Baines, T. (2017a), "Product-service innovation and performance: the role of collaborative partnerships and R\&D intensity", $R \& D$ Management, In Press.

Bustinza, O.F., Vendrell-Herrero, F. and Baines, T. (2017b), "Service implementation in manufacturing: an organisational transformation perspective, International Journal of Production Economics, Vol. 192, pp. 1-8.

Bustinza, O.F., Gomes, E., Vendrell-Herrero, F., and Tarba, S. (2018), “An organisational change framework for digital servitization: evidence from the Veneto region". Strategic Change, Vol. 27 No. 2, pp. 111-119. 
Carmeli. A., Zivan, I., Gomes. E. and Markman. G. (2017), 'Underlining micro socio-psychological mechanisms in buyer-supplier relationships: implications for inter-organizational learning agility,' Human Resource Management Review, In Press.

Collinson, S.C. and Liu, Y. (2017), "Recombination for innovation: performance outcomes from international partnerships in China", $R \& D$ Management, In Press.

Craig, C.S. and Douglas, S.P. (2005), International Marketing Research, John Wiley \& Sons, Chichester, UK.

Crozet, M. and Milet, E. (2017), "Should everybody be in services? The effect of servitization on manufacturing firm performance", Journal of Economics \& Management Strategy, Vol. 26 No. 4, pp. 820-841.

Cui, L., Meyer, K. E. and Hu, H. W. (2014), “What drives firms' intent to seek strategic assets by foreign direct investment? A study of emerging economy firms", Journal of World Business, Vol. 49 No. 4, pp. 488-501.

Cunha, M.P., Gomes, E., Mellahi, K., Miner, A. and Rego, A. (2018), "Strategic agility through improvisational capabilities: implications for a paradox-sensitive HRM", Human Resource Management Review, In Press.

Damijan, J.P., Rojec, M., Majcen, B. and Knell, M. (2013), "Impact of firm heterogeneity on direct and spillover effects of FDI: micro-evidence from ten transition countries", Journal of Comparative Economics, Vol. 41 No. 3, pp. 895-922.

Doz, Y. L. and Kosonen, M. (2008a). Fast strategy: How strategic agility will help you stay ahead of the game. Pearson Education, New York.

Doz, Y.L. and Kosonen, M. (2008b). The dynamics of strategic agility: Nokia's rollercoaster experience. California Management Review, Vol. 50 No. 3, pp. 95-118.

Doz, Y.L., and Kosonen, M. (2010), “Embedding strategic agility: a leadership agenda for accelerating business model renewal", Long Range Planning, Vol. 43 No. 2-3, pp. 370-382.

Du, L., Harrison A. and Jefferson G.H. (2012), "Testing for horizontal and vertical foreign investment spillovers in China, 1998-2007", Journal of Asian Economics, Vol. 23 No. 3, pp. 234-243. 
Dyer, L. and Ericksen, J. (2005), "In pursuit of marketplace agility: applying precepts of self-organizing systems to optimize human resource scalability", Human Resource Management, Vol. 44 No. 2, pp. 183-188.

Feenstra, R.C., Li, Z. and Yu, M. (2014), “Exports and credit constraints under incomplete information: theory and evidence from China", The Review of Economics and Statistics, Vol. 96 No. 4, pp. 729-744.

Feng, L., Li, Z. and Swenson, D.L. (2016), “The connection between imported intermediate inputs and exports: evidence from Chinese enterprises", Journal of International Economics, Vol. 101, pp. 86-101.

Fourné, S.P., Jansen, J.J. and Mom, T.J. (2014), “Strategic agility in MNEs”, California Management Review, Vol. 56 No. 3, pp. 13-38.

Gibson, C.B. and Birkinshaw, J. (2004), "The antecedents, consequences, and mediating role of organizational ambidexterity", Academy of Management Journal, Vol. 47 No. 2, pp. 209-226.

Girma, S. and Gong, Y. (2008), "FDI, linkages and the efficiency of state-owned enterprises in China”, The Journal of Development Studies, Vol. 44 No. 5, pp. 728-749.

Gomes, E., Vendrell-Herrero, F., Mellahi, K., Angwin, D., and Sousa, C. (2018), "Testing the self-selection theory in high corruption environments: evidence from African SMEs", International Marketing Review, Forthcoming.

Green, M.H., Davies, P. and Ng, I.C. (2017), “Two strands of servitization: a thematic analysis of traditional and customer co-created servitization and future research directions", International Journal of Production Economics, Vol. 192, pp. 40-53.

Gupta, A.K., Smith, K.G. and Shalley, C.E. (2006), “The interplay between exploration and exploitation", Academy of Management Journal, Vol. 49 No. 4, pp. 693-706.

Hallak, J.C. and Schott, P.K. (2011), "Estimating cross-country differences in product quality", Quarterly Journal of Economics, Vol. 126 No. 1, pp. 417-474.

Herzer, D. (2012), "How does foreign direct investment really affect developing countries' growth?", Review of International Economics, Vol. 20 No. 2, pp. 396-414. 
Jain, S.C. (1989), "Standardization of international marketing strategy: some research hypotheses", The Journal of Marketing, Vol. 53 No. 1, pp. 70-79.

Javorcik, B.S. and Spatareanu M. (2011), "Does it matter where you come from? vertical spillovers from foreign direct investment and the origin of investors ", Journal of Development Economics, Vol. 96 No. 1, pp. 126-138.

Junni, P., Sarala, R.M., Tarba, S.Y. and Weber, Y. (2015), "The role of strategic agility in acquisitions", British Journal of Management, Vol. 26 No. 4, pp. 596-616.

Levinsohn, J. and Petrin, A. (2003), "Estimating production functions using inputs to control for unobservables", Review of Economic Studies, Vol. 70 No. 2, pp. 317-342.

Lewis, M.W., Andriopoulos, C., and Smith, W.K. (2014), "Paradoxical leadership to enable strategic agility”, California Management Review, Vol. 56 No. 3, pp. 58-77.

Li, J.H., Lin, L., Chen, D.P. and Ma, L.Y. (2015), “An empirical study of servitization paradox in China", The Journal of High Technology Management Research, Vol. 26 No. 1 , pp. 66-76.

Lin, C.T., Chiu, H. and Chu, P.Y. (2006), “Agility index in the supply chain”, International Journal of Production Economics, Vol. 100, pp. 285-299.

Liu, Y. and Huang, Q. (2018), "University capability as a micro-foundation for the Triple Helix model: the case of China", Technovation, In Press. First published: 16 March 2018.

Liu, X., Wang C. and Wei Y. (2009), "Do local manufacturing firms benefit from transactional linkages with multinational enterprises in China?", Journal of International Business Studies, Vol. 40 No. 7, pp. 1113-1130.

Liu, Y. and Woywode, M. (2013), "Light-touch integration of Chinese cross-border M\&A: the influences of culture and absorptive capacity", Thunderbird International Business Review, Vol. 55 No. 4, pp. 469-483.

Liu, Y. (2017), “Born global firms' growth and collaborative entry mode: the role of transnational entrepreneurs", International Marketing Review, Vol. 34, No. 1, pp. 46-67. 
Liu, Y., and Vrontis, D. (2017), "Emerging markets firms venturing into advanced economies: The role of context", Thunderbird International Business Review, Vol. 59 No.3, pp. 255-261.

Liu, Y., Öberg, C., Tarba, S.Y., and Xing, Y. (2017), "Brand management in mergers and acquisitions: emerging market multinationals venturing into advanced economies", International Marketing Review, Forthcoming.

Lodefalk, M. (2014), "The role of services for manufacturing firm exports", Review of World Economics, Vol. 150, pp. 59-82.

Lovelock, C. (1991), Services Marketing, Prentice Hall, Englewood Cliffs, NJ.

Lukka, K., \& Vinnari, E. (2014). Domain theory and method theory in management accounting research. Accounting, Auditing \& Accountability Journal, 27(8), 1308-1338.

Melitz, M.J. (2003), “The impact of trade on intra-industry reallocations and aggregate industry productivity”, Econometrica, Vol. 71 No. 6, pp. 1695-1725.

Meyer K.E. and Sinani E. (2009), " When and where does foreign direct investment generate positive spillovers? a meta-analysis ", Journal of International Business Studies, Vol. 40 No. 7, pp. 1075-1094.

Oliva, R. and Kallenberg, R. (2003), "Managing the transition from products to services", International Journal of Service Industry Management, Vol. 12 No. 2, pp. 160-172.

Rabetino, R., Harmsen, W., Kohtamäki, M. and Sihvonen, J. (2018), “Structuring servitization-related research", International Journal of Operations \& Production Management, Vol. 38 No. 2, pp. 350-371.

Raff, H. and Ruhr, M. (2007), "Foreign direct investment in producer services: theory and empirical evidence", Applied Economics Quarterly, Vol. 53 No. 3, pp. 299-321.

Ricart, J.E., Enright, M.J., Ghemawat, P., Hart, S.L. and Khanna, T. (2004), "New frontiers in international strategy", Journal of International Business Studies, Vol. 35 No. 3, pp. $175-200$. 
Sambamurthy, V., Bharadwaj, A. and Grover, V. (2003), "Shaping agility through digital options: reconceptualizing the role of Information Technology in contemporary enterprises”, MIS Quarterly, Vol. 27 No. 2, pp. 237-263

Schmid, S. and Kotulla, T. (2011), "50 years of research on international standardization and adaptation: from a systematic literature analysis to a theoretical framework", International Business Review, Vol. 20 No. 5, pp. 491-507.

Shenkar, O. (2010), "Copycats: how smart companies use imitation to gain a strategic edge", Strategic Direction, Vol. 26 No. 10, pp. 3-5.

Souchon, A.L., Hughes, P., Hughes, P., Farrell, A.M., Nemkova, E. and Oliveira, J.S. (2016), "Spontaneity and international marketing performance", International Marketing Review, Vol. 33 No. 5, pp. 671-690.

Sun, P.Y., Jiang, W. and Chen, W. (2015), "FDI liberalization, technology distance and enterprises' export in China: based on the appointment of upstream and downstream industry linkage", Management World, Vol. 10, pp. 32-48.

Tan, Q. and Sousa, C.M. (2013), “International marketing standardization”, Management International Review, Vol. 53 No. 5, pp. 711-739.

Tukker, A. (2004), "Eight types of product-service system: eight ways to sustainability? Experiences from SusProNet", Business Strategy and the Environment, Vol. 13 No. 4, pp. 246-260.

Utterback, J.M. and Abernathy, W.J. (1975), “A dynamic model of process and product innovation", Omega, Vol. 3 No. 6, pp. 639-656.

Vandermerwe, S. and Rada, J. (1988), "Servitization of business: adding value by adding services", European Management Journal, Vol. 6 No. 4, pp. 314-324.

Vargo, S.L. and Lusch, R.F. (2004), “The four service marketing myths: remnants of a goods-based, manufacturing model”, Journal of Service Research, Vol. 6 No. 4, pp. 324-335.

Vendrell-Herrero, F., Gomes, E., Mellahi, K. and Child, J. (2017), "Building international business bridges in geographically isolated areas: the role of Foreign Market Focus and 
Outward Looking Competences in Latin American SMEs", Journal of World Business, Vol. 52 No. 4, pp. 489-502

Vendrell-Herrero, F., Parry, G., Opazo-Basaez, M. and and Sanchez-Montesinos, F. (2018), "Does business model experimentation in dynamic contexts enhance value capture? International Journal of Business Environment", Vol. 10 No. 1, pp. 14-34.

Vendrell-Herrero, F., Gomes, E., Collinson, S., Parry, G. and Bustinza, O.F. (2018), “Selling digital services abroad: how do extrinsic attributes influence foreign consumers' purchase intentions?, International Business Review, Vol. 27 No. 1, pp. 173-185.

Vendrell-Herrero, F., Gomes, E., Bustinza, O.F. and Mellahi, K. (2018), "Uncovering the role of cross-border strategic alliances and expertise decision centralization in enhancing product-service innovation in MMNEs", International Business Review, Vol. 27 No. 4, pp. $814-825$.

Verma, V., Bharadwaj, S.S. and Nanda, M. (2017), “Comparing agility and absorptive capacity for superior firm performance in dynamic environment", International Journal of Business Environment, Vol. 9 No. 1, pp. 1-17.

Weber, Y. and Tarba, S.Y. (2014), "Strategic agility: a state of the art", California Management Review, Vol. 56 No. 3, pp. 5-12.

Weill, P., Subramani, M. and Broadbent, M. (2002), "Building IT infrastructure for strategic agility”, MIT Sloan Management Review, Vol. 44 No. 1, pp. 57-65.

Xing, Y. and Liu, Y. (2015), "Poetry and leadership in light of ambiguity and logic of appropriateness", Management and Organization Review, Vo. 11 No. 4, pp. 763-793.

Xing, Y., Liu, Y., Tarba, S.Y., and Cooper, C.L. (2016), “Intercultural influences on managing African employees of Chinese firms in Africa: chinese managers' HRM practices", International Business Review, Vol. 25 No. 1, pp. 28-41.

Xing, Y., Liu, Y., Tarba, S., and Cooper, C.L. (2017), "Servitization in mergers and acquisitions: manufacturing firms venturing from emerging markets into advanced economies", International Journal of Production Economics, Vol.192, pp. 9-18. 
Xing, Y, Liu, Y. and Cooper, C. (2018), "Local government as institutional entrepreneur: collaborative partnerships in fostering regional entrepreneurship", British Journal of Management, First published: 27 February 2018.

Xu, J.Y., Mao, Q.L. and Xu, A.G. (2017), “Intermediate input imports and the quality upgrading of export product: evidence from Chinese manufacturing enterprise", The Journal of World Economy, Vol. 3, pp. 52-75.

Yu, M.J. and Tian, W. (2012), “China's processing trade: a firm-level analysis”, in McMay, H. and Song, L. (Eds.), Rebalancing and Sustaining Growth in China, Australian National University E-press, pp. 111-148.

Zhang, Y, Tang, Y.H. and Zhou, M.H. (2013), "Does service liberalization increase productivity of the manufacturing enterprises?", Journal of World Economy, Vol. 11, pp. 51-71.

Zhang, Y. A., Li, Y. and Li, H. (2014), "FDI spillovers over time in an emerging market: the roles of entry tenure and barriers to imitation", Academy of Management Journal, Vol. 57 No. 57, pp. 698-722. 